K.N. Ospanov, Zh.B. Yeskabylova

L.N. Gumilyov Eurasian National University, Nur-Sultan, Kazakhstan

(E-mail: ospanov_kn@enu.kz, juli_e92@mail.ru)

\title{
Conditions of coercive solvability of third-order differential equation with unbounded intermediate coefficients
}

\begin{abstract}
In this paper we study the following equation $-y^{\prime \prime \prime}+r(x) y^{\prime \prime}+q(x) y^{\prime}+s(x) y=f(x)$, where the intermediate coefficients $r$ and $q$ do not depend on $s$. We give the conditions of the coercive solvability for $f \in L_{2}(-\infty,+\infty)$ of this equation. For the solution $y$, we obtained the following maximal regularity estimate: $\left\|y^{\prime \prime \prime}\right\|_{2}+\left\|r y^{\prime \prime}\right\|_{2}+\left\|q y^{\prime}\right\|_{2}+\|s y\|_{2} \leq C\|f\|_{2}$, where $\|\cdot\|_{2}$ is the norm of $L_{2}(-\infty,+\infty)$. This estimate is important for study of the qwasilinear third-order differential equation in $(-\infty,+\infty)$. We investigate some binomial degenerate differential equations and we prove that they are coercive solvable. Here we apply the method of the separability theory for differential operators in a Hilbert space, wich was developed by M. Otelbaev. Using these auxillary statements and some well-known Hardy type weighted integral inequalities, we obtain the desired result. In contrast to the preliminary results, we do not assume that the coefficient $s$ is strict positive, the results are also valid in the case that $s=0$.
\end{abstract}

Keywords: differential equation, unbounded coefficients, maximal regularity, separability.

\section{Introduction and Main Theorems}

We consider the following linear differential equation:

$$
L_{0} y \equiv-y^{\prime \prime \prime}+r(x) y^{\prime \prime}+q(x) y^{\prime}+s(x) y=f(x),
$$

where $x \in R=(-\infty,+\infty)$ and $f \in L_{2}:=L_{2}(R)$. By $C_{l o c}^{(j)}(R)(j=0,1,2, \ldots)$ we denote the set of the $j$-times continuously differentiable functions in the every compact, $C_{l o c}^{(0)}(R)=C_{l o c}(R)$ is the set of the continuous functions. We assume that $r \in C_{l o c}^{(2)}(R), q \in C_{l o c}^{(1)}(R), s \in C_{l o c}(R)$ in (1.1) are real functions, in general, they are unbounded. We denote by $L$ the closure in $L_{2}$ of the operator $L_{0}$ defined on the set of three times continuously differentiable functions with compact support $C_{0}^{(3)}(R)$.

Definition 1.1. The function $y \in L_{2}$ is called a solution of the equation (1.1), if $y \in D(L)$ and $L y=f$.

In future, by $C, C_{1}, C_{2}$ and etc. we will denote the positive constants, which, generally speaking, are different in the different places.

Definition 1.2. The solution $y$ of the equation (1.1) is called a maximally $L_{2}$-regular, if the following estimate holds:

$$
\left\|y^{\prime \prime \prime}\right\|_{2}+\left\|r y^{\prime \prime}\right\|_{2}+\left\|q y^{\prime}\right\|_{2}+\|s y\|_{2} \leq C\|f\|_{2},
$$

where $\|\cdot\|_{2}$ is a norm in $L_{2}$. The inequality (1.2) is called the maximal $L_{2}$-regularity estimate. If (1.2) holds, then the operator $L$ is said to be separable in $L_{2}$.

The purpose of this work is to find the sufficient conditions for correct solvability of the equation (1.1) and the fullfilment of the estimate (1.2) for a solution of the equation (1.1). The important examples of the equation (1.1) are the Korteweg-de Vries equation (linearized) and its modifications that describe the wave propagation and are used in the problems of a gas dynamics (see [1] and the references therein), as well as the composite type equations that are used in the hydrodynamics and hydromechanics [2]. Furthermore, the equation (1.1) appear in the case that we apply the Fourier method to the partial differential equations of mathematical physics. The other applications of the third-order differential equations can be seen in [3-6].

The smoothness problems for solutions of the equation (1.1) are of a great interest. The case of the bounded domains and smooth scalar coefficients are well understood and sufficiently well described in the known literature. In the case that the domain is unbounded, although the solution of the odd-order equation (1.1) is local smooth, but it may not belong to the Sobolev spaces. This fact causes some difficulties for study of (1.1). 
The estimate (1.2) is very important for the study of singular nonlinear differential equations [7]. The maximal regularity problem for the second-order partial differential equations were investigated by P.C. Kunstmann, W. Arendt, M. Duelli, G. Metafune, D. Pallara, J. Prüss, R. Schnaubelt, A. Rhandi [7-10] in the case that their intermediate coefficients are unbounded, although they were controlled by the potential. This problem for a degenerate second-order differential operator was studied in [11].

The maximal regularity (separability) problem for a singular third-order equation has been investigated, mainly, for the following two-terms equation (see [12-19] and the references therein)

$$
K y=-y^{\prime \prime \prime}+s(x) y=F(x)(x \in(-\infty,+\infty)) .
$$

In [12-19] were obtained conditions for the continuous invertibility and separability of the operator $K$ in $L_{p}(R)$ $(1<p<+\infty)$. However, we can not use their results to investigate of the equation (1.1) with unbounded intermediate coefficients. In general, in the case that the intermediate coefficients have more faster growth, the equations (1.1) and (1.3) are different. For example, the solution of (1.1) belongs to $L_{2}$ in the case only that the functions $r$ and $q$ satisfy some additional conditions. The question of maximum regularity for other elliptic and parabolic equations defined in infinite domains has been investigated in many papers [20-35].

In the present paper, we consider the following two cases for the intermediate coefficients $r$ and $q$ of (1.1):

a) the growth of the function $r$ does not depend on $q$ and $s$;

b) the growth of the function $q$ does not depend on $r$ and $s$.

For continuous functions $p$ and $v \neq 0$, we denote

$$
\begin{gathered}
\alpha_{p, v, j}(x)=\left(\int_{0}^{x}|p(t)|^{2} d t\right)^{\frac{1}{2}} \cdot\left(\int_{x}^{+\infty} t^{2 j} v^{-2}(t) d t\right)^{\frac{1}{2}}, x>0, \\
\beta_{p, v, j}(\tau)=\left(\int_{\tau}^{0}|p(t)|^{2} d t\right)^{\frac{1}{2}} \cdot\left(\int_{-\infty}^{\tau} t^{2 j} v^{-2}(t) d t\right)^{\frac{1}{2}}, \tau<0, \\
\gamma_{p, v, j}=\max \left(\sup _{x>0} \alpha_{p, v, j}(x), \sup _{\tau<0} \beta_{p, v, j}(\tau)\right)(j=0,1),
\end{gathered}
$$

Theorem 1.1. Assume that the functions $r, q$ and $s$ satisfy the following conditions:

$$
\begin{gathered}
r \in C_{l o c}^{(2)}(R),|r| \geq 1, q \in C_{l o c}^{(1)}(R), s \in C_{l o c}(R), \\
\gamma_{1, \sqrt{|r|}, 1}<\infty, C_{0}^{-1} \leq \frac{r(x)}{r(\eta)} \leq C_{0}, \forall x, \eta \in R:|x-\eta| \leq 1, C_{0}>1, \\
\gamma_{q, r, 0}<\infty, \gamma_{s, r, 1}<\infty .
\end{gathered}
$$

Then for any right-hand side $f \in L_{2}$ there exists a unique solution $y$ of the equation (1.1). Moreover, for $y$ the estimate (1.2) holds.

In the theorem the growth of coefficients $q$ and $s$ are controlled by $r$.

Remark 1.1. The condition $|r| \geq 1$ in (1.4) can be replaced by the inequality $|r| \geq \delta>0$. To show this statement it is enough to put $x=\sqrt{\delta} t$ in (1.1), where $t \in R$.

The following equation:

$$
-y^{\prime \prime \prime}+\left(7 x^{2}+3\right)^{4} y^{\prime \prime}+\left(2 x^{3}-3 x^{2}+1\right) y^{\prime}+x^{3} y=f_{1}, f_{1} \in L_{2},
$$

satisfies (see Example 2.1 below) the conditions of Theorem 1.1, consequently, the equation (1.7) is uniquely solvable, and for its solution $y$ the following estimate holds:

$$
\left\|y^{\prime \prime \prime}\right\|_{2}+\left\|\left(7 x^{2}+3\right)^{4} y^{\prime \prime}\right\|_{2}+\left\|\left(2 x^{3}-3 x^{2}+1\right) y^{\prime}\right\|_{2}+\left\|x^{3} y\right\|_{2} \leq C\left\|f_{1}\right\|_{2} .
$$

In the following theorem the growth of $r$ and $s$ are controlled by coefficient $q$.

Theorem 1.2. Assume that the functions $r \in C_{l o c}^{(2)}(R), q \in C_{l o c}^{(1)}(R)$ and $s \in C_{l o c}(R)$ satisfy the following conditions:

$$
\begin{gathered}
q \geq 1, \gamma_{1, \sqrt{q}, 0<\infty, C_{1}^{-1} \leq} \frac{q(x)}{q(\eta)} \leq C_{1}, \forall x, \eta \in R:|x-\eta| \leq 1,\left(C_{1}>1\right) \\
\gamma_{s, q, 0}<\infty \\
2\left(r^{2}+2 r^{\prime}\right) \leq q .
\end{gathered}
$$


Then for any $f \in L_{2}$ there exists a unique solution $y$ of the equation (1.1). Moreover, for $y$ the estimate (1.2) holds.

Remark 1.2. In Theorem 1.2 the condition $q \geq 1$ can be replaced by $q \geq \delta>0$. To show this statement it is enough to put $x=\delta t$ in the equation (1.1).

The conditions of Theorem 1.2 satisfy the coefficients of the following equation:

$$
-y^{\prime \prime \prime}+x^{3} \cos ^{2} x^{2} y^{\prime \prime}+\left[18\left(1+x^{6}\right)\right] y^{\prime}+3 x^{4} y=f_{2}(x)
$$

(see Example 3.1 below).

\section{The case that the coefficient $r$ is growing independently}

In this section we investigate the equation (1.1) in the case that the growth of the function $r$ does not depend on $q$ and $s$. First, we consider the following linear two term differential equation:

$$
l_{0} y=-y^{\prime \prime \prime}+r(x) y^{\prime \prime}=h(x)
$$

where $x \in R, h \in L_{2}$, and $r \in C_{l o c}^{(2)}(R)$. We denote by $l$ the closure in $L_{2}$ of the operator $l_{0}$ defined on the set of three times continuously differentiable functions with compact support $C_{0}^{(3)}(R)$.

Definition 2.1. The function $y \in L_{2}$ is called a solution of the equation (2.1), if $y \in D(l)$ and $l y=h$.

The following statement is proved in [36].

Lemma 2.1. Let the function $r$ be a twice continuously differentiable function and it satisfies the following conditions:

$$
\begin{gathered}
r \geq \delta>0, \gamma_{1, \sqrt{r}, 1}<\infty \\
C^{-1} \leq \frac{r(x)}{r(\eta)} \leq C \forall x, \eta \in R:|x-\eta| \leq 1, C>1 .
\end{gathered}
$$

Then for any right - hand side $h \in L_{2}$ there exists a unique solution $y$ of the equation (2.1). Moreover, for $y$ the following estimate holds (i.e. $y$ is maximally $L_{2}$-regular):

$$
\left\|y^{\prime \prime \prime}\right\|_{2}+\left\|r y^{\prime \prime}\right\|_{2} \leq C_{l}\|h\|_{2} .
$$

Proof of Theorem 1.1. We put $x=a t(0>0, t$ is new variable $)$ in the equation (1.1). Then (1.1) become the following form:

$$
\tilde{L}_{a} \tilde{y}=-\tilde{y}^{\prime \prime \prime}+a \tilde{r}(t) \tilde{y}^{\prime \prime}+a^{2} \tilde{q}(t) \tilde{y}^{\prime}+a^{3} \tilde{s}(t) \tilde{y}=\tilde{f}(t)
$$

where $y(a t)=\tilde{y}(t), r(a t)=\tilde{r}(t), q(a t)=\tilde{q}(t), s(a t)=\tilde{s}(t), a^{3} f(a t)=\tilde{f}(t)$ and $a^{3} L_{a} y=\tilde{L}_{a} \tilde{y}$. First, we consider the following equation:

$$
l_{0 a} \tilde{y}=-\tilde{y}^{\prime \prime \prime}+a \tilde{r}(t) \tilde{y}^{\prime \prime}=\tilde{h}(t)
$$

We denote by $l_{a}$ a closure in $L_{2}$ of the operator $l_{0 a}$ defined in $C_{0}^{(3)}(R)$. We have $a^{-1} \tilde{r}(t) \geq \delta>0$. By Remark 1.1 and Lemma 2.1, for any function $\tilde{h} \in L_{2}$ there exists a unique solution $\tilde{y}$ of the equation (2.3) and for $\tilde{y}$ the following estimate holds:

$$
\left\|\tilde{y}^{\prime \prime \prime}\right\|_{2}+\left\|a \tilde{r} \tilde{y}^{\prime \prime}\right\|_{2} \leq C_{l_{a}}\left\|l_{a} \tilde{y}\right\|_{2}, \forall \tilde{y} \in D\left(l_{a}\right)
$$

Using (2.4), by Theorem 2.1 in [37] and Lemma 2.1 [11], we have

$$
\left\|a^{2} \tilde{q} \tilde{y}^{\prime}\right\|_{2} \leq 2 a \gamma_{\tilde{q}, \tilde{r}, 0} C_{l_{a}}\left\|l_{a} \tilde{y}\right\|_{2}
$$

and

If we choose

$$
\left\|a^{3} \tilde{s} \tilde{y}\right\|_{2} \leq 2 a^{2} \gamma_{\tilde{s}, \tilde{r}, 1} C_{l_{a}}\left\|l_{a} \tilde{y}\right\|_{2}
$$

$$
a=\left[2\left(\gamma_{\tilde{q}, \tilde{r}, 0}+a \gamma_{\tilde{s}, \tilde{r}, 1}\right) C_{l_{a}}+1\right]^{-1},
$$

then, by (2.5) and (2.6), the following estimate holds:

$$
\left\|a^{2} \tilde{q} \tilde{y}^{\prime}\right\|_{2}+\left\|a^{3} \tilde{s} \tilde{y}\right\|_{2} \leq \theta\left\|l_{a} \tilde{y}\right\|_{2}
$$


where

$$
0<\theta=\frac{2\left(\gamma_{\tilde{q}, \tilde{r}, 0}+\gamma_{\tilde{s}, \tilde{r}, 1}\right) C_{l_{a}}}{2\left(\gamma_{\tilde{q}, \tilde{r}, 0}+\gamma_{\tilde{s}, \tilde{r}, 1}\right) C_{l_{a}}+1}<1 .
$$

Then by Lemma 2.1 and the well-known perturbation theorem [38; 196], there exists a unique solution of the equation (2.2).

Now, we show the maximal $L_{2}$-regularity estimate for a solution of the equation (2.2). By (2.7),

$$
\left\|l_{a} \tilde{y}\right\|_{2} \leq\left\|l_{a} \tilde{y}+a^{2} \tilde{q} \tilde{y}^{\prime}+a^{3} \tilde{s} \tilde{y}\right\|_{2}+\left\|a^{2} \tilde{q} \tilde{y}^{\prime}+a^{3} \tilde{s} \tilde{y}\right\|_{2} \leq\left\|\tilde{L}_{a} \tilde{y}\right\|_{2}+\theta\left\|l_{a} \tilde{y}\right\|_{2}
$$

$(0<\alpha<1)$. Consequently

$$
\left\|l_{a} \tilde{y}\right\|_{2} \leq \frac{1}{1-\theta}\left\|\tilde{L}_{a} \tilde{y}\right\|_{2}
$$

By the estimates (2.4), (2.7) and (2.8),

$$
\left\|\tilde{y}^{\prime \prime \prime}\right\|_{2}+\left\|a \tilde{r} \tilde{y}^{\prime \prime}\right\|_{2}+\left\|a^{2} \tilde{q} \tilde{y}^{\prime}\right\|_{2}+\left\|a^{3} \tilde{s} \tilde{y}\right\|_{2} \leq \frac{C_{l_{a}}+\theta}{1-\theta}\left\|\tilde{L}_{a} \tilde{y}\right\|_{2} .
$$

(2.9) is the desired estimate for a solution $\tilde{y}$ of the equation (2.2). By replacing $t=\frac{x}{a}$, we get that there exists a unique solution y of the equation (1.1), moreover, for it the estimate (1.7) holds.

Example 2.1. We consider the following equation

$$
-y^{\prime \prime \prime}+\left(7 x^{2}+3\right)^{4} y^{\prime \prime}+\left(2 x^{3}-3 x^{2}+1\right) y^{\prime}+x^{3} y=f_{1}(x),
$$

where $x \in R, f_{1}(x) \in L_{2}$. Here, $r=\left(7 x^{2}+3\right)^{4}, q=2 x^{3}-3 x^{2}+1$ and $s=x^{3}$. The intermediate coefficients $r$ and $q$ satisfy conditions (1.4), (1.5), and (1.6) of Theorem 1.1. In fact, since the function $\left(7 x^{2}+3\right)^{4}$ is even, for any $x>0$

$$
\alpha_{1, \sqrt{r}, 1}(x)=\beta_{1, \sqrt{r}, 1}(-x) \leq \sqrt{x}\left(\int_{x}^{+\infty} \frac{d t}{\left(7 t^{2}+3\right)^{4}}\right)^{\frac{1}{2}} \leq \frac{\sqrt{x}}{\left(7 x^{2}+3\right)^{3}}\left(\int_{x}^{+\infty} \frac{d t}{7 t^{2}+3}\right)^{\frac{1}{2}}<\infty .
$$

Analogously, we obtain

$$
\begin{gathered}
\alpha_{q, r, 0}(x)=\beta_{q, r, 0}(-x) \leq\left(\int_{0}^{x} 3\left(4 t^{6}+9 t^{4}+1\right) d t\right)^{\frac{1}{2}}\left(\int_{x}^{+\infty} \frac{d t}{\left(7 t^{2}+3\right)^{8}}\right)^{\frac{1}{2}} \leq \\
\leq \frac{\left(\frac{12}{7} x^{7}+\frac{9}{5} x^{5}+x\right)^{\frac{1}{2}}}{\left(7 x^{2}+3\right)^{7}}\left(\int_{x}^{+\infty} \frac{d t}{7 t^{2}+3}\right)^{\frac{1}{2}}<\infty
\end{gathered}
$$

and

$$
\alpha_{s, r, 1}(x)=\beta_{s, r, 1}(-x) \leq\left(\int_{0}^{x}\left|t^{3}\right|^{2} d t\right)^{\frac{1}{2}}\left(\int_{x}^{+\infty} t^{2}\left(7 t^{2}+3\right)^{-8} d t\right)^{\frac{1}{2}}<\infty .
$$

For any $x, \eta \in R$ such that $|x-\eta| \leq 1$

$$
\frac{\left(7 x^{2}+3\right)^{4}}{\left(7 \eta^{2}+3\right)^{4}} \leq \frac{\left[6\left(7 \eta^{2}+3\right)\right]^{4}}{\left(7 \eta^{2}+3\right)^{4}}=1296
$$

So, by Theorem 1.1, for any $f_{1} \in L_{2}$ there exists a unique solution $y$ of the equation (1.7) and for it the estimate (1.8) holds. 


\section{The case that the coefficient $q$ is growing independently}

In this section we consider the equation (1.1) in the case that the function $q$ is fast growing function. First, we consider the following differential equation:

$$
\tilde{l}_{0} y=-y^{\prime \prime \prime}+q(x) y^{\prime}=u(x), x \in R, u \in L_{2} .
$$

We denote by $\tilde{l}$ a closure in $L_{2}$ of the operator $\tilde{l}_{0} y=-y^{\prime \prime \prime}+q(x) y^{\prime}$ defined in $C_{0}^{(3)}(R)$. The element $y \in D(\tilde{l})$ such as $\tilde{l} y=u$, is called a solution of the equation (3.1).

Lemma 3.1. If $q(x)$ is continuously differentiable function such as

$$
q \geq 1, \gamma_{1, \sqrt{q}, 0}<\infty
$$

then for any $u \in L_{2}$ there exists a unique solution $y$ of the equation (3.1). Moreover, for $y$ the following estimate holds:

$$
\left\|\sqrt{q} y^{\prime}\right\|_{2}+\|y\|_{2} \leq C\|\tilde{l} y\|_{2} .
$$

Proof. Let $y \in C_{0}^{(3)}(R)$. Integrating by parts, we have

$$
\left(\tilde{l}_{0} y, y^{\prime}\right)=\left\|y^{\prime \prime}\right\|_{2}^{2}+\left\|\sqrt{q} y^{\prime}\right\|_{2}^{2} .
$$

Taking into account the condition (3.2), by the Holder inequality, we obtain

$$
\left|\left(\tilde{l}_{0} y, y^{\prime}\right)\right| \leq\left\|\frac{1}{\sqrt{q}} \tilde{l}_{0} y\right\|_{2}\left\|\sqrt{q} y^{\prime}\right\|_{2} .
$$

Then by (3.2) and (3.4),

$$
\|y\|_{2} \leq 2 \gamma_{1, \sqrt{q}, 0}\left\|\sqrt{q} y^{\prime}\right\|_{2} \leq 2 \gamma_{1, \sqrt{q}, 0}\left\|\frac{1}{\sqrt{q}} \tilde{l}_{0} y\right\|_{2}
$$

and

$$
\|y\|_{2}+\left\|\sqrt{q} y^{\prime}\right\|_{2} \leq\left[2 \gamma_{1, \sqrt{q}, 0}+1\right]\left\|\tilde{l}_{0} y\right\|_{2}, y \in C_{0}^{(3)}(R) .
$$

Further, we show that the estimate (3.5) holds for any $y \in D(l)$. Let $\left\{y_{n}\right\}_{n=1}^{\infty} \subset C_{0}^{(3)}(R)$ such sequence that

$$
\left\|y_{n}-y\right\|_{2} \rightarrow 0,\left\|\tilde{l}_{0} y_{n}-l y\right\|_{2} \rightarrow 0(n \rightarrow \infty) .
$$

By (3.5), for any $y_{n}, y_{m} \in C_{0}^{(3)}(R)$

$$
\left\|y_{n}\right\|_{2}+\left\|\sqrt{q} y_{n}^{\prime}\right\|_{2} \leq\left[2 \gamma_{1, \sqrt{q}, 0}+1\right]\left\|\tilde{l}_{0} y_{n}\right\|_{2}
$$

and

$$
\left\|y_{n}-y_{m}\right\|_{2}+\left\|\sqrt{q}\left(y_{n}^{\prime}-y_{m}^{\prime}\right)\right\|_{2} \leq\left[2 \gamma_{1, \sqrt{q}, 0}+1\right]\left\|\tilde{l}_{0} y_{n}-\tilde{l}_{0} y_{m}\right\|_{2} .
$$

We denote by $W_{2, \sqrt{q}}^{1}(R)$ the completion of $C_{0}^{(3)}(R)$ with respect to the norm $\|y\|_{W}=\left\|\sqrt{q} y^{\prime}\right\|_{2}+\|y\|_{2}$. According to (3.8), $\left\{y_{n}\right\}_{n=1}^{\infty}$ is a Cauchy sequence in $W_{2, \sqrt{q}}^{1}(R) . W_{2, \sqrt{q}}^{1}(R)$ is a Banach space, therefore there exists an element $z$ such as $\left\|y_{n}-z\right\|_{W} \rightarrow 0(n \rightarrow \infty)$. Then by (3.6), $z \in D(l)$, furthermore, $z$ is a solution of (3.1). Passing to the limit at $n \rightarrow \infty$ in (3.7), we obtain the inequality (3.3) for $z$ with $C=2 \gamma_{1, \sqrt{q}, 0}+1$.

By (3.3) and Definition 2.1, there exists the inverse $\tilde{l}^{-1}$ to the operator $\tilde{l}$. So, a solution of the equation (3.1) is unique.

We show, that for any $u \in L_{2}$ there exists a solution of the equation (3.1). By Definition 2.1, it is sufficient to prove that $R(\tilde{l})=L_{2}$. Assume the contrary, let $R(\tilde{l}) \neq L_{2}$. Then there exists the non-zero element $z(x) \in R(\tilde{l})^{\perp}:(\tilde{l} y, z)=0$ for any $y \in C_{0}^{(3)}(R)$. On the other hand

$$
(\tilde{l} y, z)=\int_{R} y\left(\bar{z}^{\prime \prime \prime}-[q(x) \bar{z}]^{\prime}\right) d x, \forall y \in C_{0}^{(3)}(R) .
$$


$C_{0}^{(3)}(R)$ is dense in $L_{2}$, so we have

$$
z^{\prime \prime}-q z=C_{1} .
$$

From (3.9), taking into account that $q(x) \in C_{l o c}^{(1)}(R)$, we have that $z(x) \in C_{l o c}^{(3)}(R)$. We consider two cases with respect to $C_{1}$.

1. $C_{1} \neq 0$. Then, we can assume, that $C_{1}=1$ :

$$
z^{\prime \prime}-q(x) z=1, x \in R
$$

The general solution $z$ of this equation belongs to $C_{l o c}^{(3)}(R)$ and is represented in the following form:

$$
z(x)=C_{2} z_{1}(x)+C_{3} z_{2}(x)+\int_{-\infty}^{+\infty} G(x, t) d t
$$

where $z_{1}(x)$ and $z_{2}(x)$ are two linearly independent solutions of the homogeneous equation $z^{\prime \prime}-q(x) z=0$ and

$$
G(x, t)= \begin{cases}z_{1}(x) z_{2}(t), & x \leq t \\ z_{2}(x) z_{1}(t), & x>t\end{cases}
$$

is the Green function of the Sturm-Liouville operator. It is known that $z_{1}(x)>0$ and $z_{2}(x)>0$. By well-known comparison theorem and maximum principle, for any $x \in R$ the following estimates hold:

$$
\left\{\begin{array}{l}
z_{1}(x) \geq K^{-1} e^{x}, 0<z_{2} \leq K e^{x}, x>0 \\
z_{2}(x) \geq K^{-1} e^{x}, 0<z_{1} \leq K e^{x}, x<0 \\
z_{1}^{\prime}(x)>0, z_{2}^{\prime}(x)<0
\end{array}\right.
$$

hence $0<G(x, t) \leq C_{4} e^{-|x-t|}$. By condition $z \in L_{2}$, we obtain $C_{2}=0$ and $C_{3}=0$. So,

$$
z(x)=\int_{-\infty}^{+\infty} G(x, t) d t>0 .
$$

By (3.10), $z^{\prime \prime}=1+q(x) z \geq 1$. Let $a \in R$ such as $z(a)=k>0$ and $z^{\prime}(a)=m>0$. By (3.2) and (3.10),

$$
z(x)-k=m(x-a)+\frac{(x-a)^{2}}{2}+\int_{a}^{x}\left(\int_{a}^{t} q z(s) d s\right) d t \geq \frac{(x-a)^{2}}{2} \forall x>a .
$$

So, $z \notin L_{2}$.

2. Let $C_{1}=0$. Then the solution $\mathrm{z}$ of the equation (3.9) is represented as follows:

$$
z(x)=C_{4} z_{1}(x)+C_{5} z_{2}(x), x \in R .
$$

As mentioned above, $z_{1}(x) \rightarrow+\infty, z_{2}(x) \rightarrow 0(x \rightarrow+\infty)$, and $z_{2}(x) \rightarrow+\infty, z_{1}(x) \rightarrow 0(x \rightarrow-\infty)$. We have $C_{4}=0$ and $C_{5}=0$. So $z(x)=0, x \in R$.

We have obtained contradictions, which show that $R(\tilde{l})=L_{2}$.

Lemma 3.2. Assume that the function $q$ satisfies conditions of Lemma 3.1 and

$$
C_{0}^{-1} \leq \frac{q(x)}{q(\eta)} \leq C_{0} \quad \forall x, \eta \in R:|x-\eta| \leq 1\left(C_{0}>1\right) .
$$

Then for the solution $y$ of the equation (3.1) the following estimate holds:

$$
\left\|y^{\prime \prime \prime}\right\|_{2}+\left\|q y^{\prime}\right\|_{2} \leq C\|\tilde{l} y\|_{2} .
$$

Proof. Let $y$ be a solution of the equation (3.1). By (3.3), $y^{\prime} \in L_{2}$. Assume, that $y^{\prime}=z$, then we obtain the following Sturm-Liouville equation:

$$
\Im z=-z^{\prime \prime}+q(x) z=\tilde{u}(x) .
$$

By conditions of Lemma, the solution $z$ of the last equation satisfies the following estimate [39; 199]:

$$
\left\|z^{\prime \prime}\right\|_{2}+\|q z\|_{2} \leq C\|\tilde{u}\|_{2} .
$$


Then for the solution $y$ of (3.1), we obtain the estimate (3.12).

Next, we will consider the following equation

$$
y^{\prime \prime \prime}+q(x) y^{\prime}+s(x) y=u_{0}(x) .
$$

Lemma 3.3. Let $q(x)$ be a continuously differentiable function, and $s(x)$ be a continuous function. Assume that the conditions (3.2) and (3.11) and the following condition

$$
\gamma_{s, q, 0}<\infty
$$

hold. Then for any $u_{0} \in L_{2}$ there exists the unique solution $y$ of the equation (3.14). Moreover, $y$ satisfies the following estimate:

$$
\left\|y^{\prime \prime \prime}\right\|_{2}+\left\|q y^{\prime}\right\|_{2}+\|s y\|_{2} \leq C\|u\|_{2} .
$$

Proof. In (3.13) we put $x=a t$, where $a>0$ and $t \in R$. Then

$$
a^{3} \tilde{l} y=-y_{t t t}^{\prime \prime \prime}(a t)+a^{2} q(a t) y_{t}^{\prime}(a t)+a^{3} s(a t) y(a t)=a^{3} u(a t) .
$$

If we introduce the notations

$$
y(a t)=\tilde{y}(t), q(a t)=\tilde{q}(t), s(a t)=\tilde{s}(t), a^{3} u(a t)=\tilde{u}(t) a^{3} \tilde{l} y=\tilde{\tilde{l}} \tilde{y},
$$

then (3.13) become the following form:

$$
\tilde{\tilde{l}} \tilde{y}=-\tilde{y}^{\prime \prime \prime}+a^{2} \tilde{q} \tilde{y}^{\prime}+a^{3} \tilde{s} \tilde{y}=\tilde{u} .
$$

We denote by $\tilde{\tilde{l}}_{a}$ a closure in $L_{2}$ of the differential expression $\tilde{\tilde{l}}_{0 a} \tilde{y}=-\tilde{y}^{\prime \prime \prime}+a^{2} \tilde{q} \tilde{y}^{\prime}$ defined on $C_{0}^{(3)}(R)$. Since $a^{2} \tilde{q}(t) \geq \delta>0$, by Lemma 3.1 and Remark 1.1, the operator $\tilde{l}_{a}$ is continuously invertible and the following estimate holds:

$$
\left\|\tilde{y}^{\prime \prime \prime}\right\|_{2}+\left\|a^{2} \tilde{q} \tilde{y}^{\prime}\right\|_{2} \leq C_{\tilde{l}_{a}}\left\|\tilde{\tilde{l}}_{a} \tilde{y}\right\|_{2}, \forall \tilde{y} \in D\left(\tilde{\tilde{l}}_{a}\right) .
$$

Taking into account the condition (3.14) and Lemma 3.1, we have

$$
\left\|a^{3} \tilde{s} \tilde{y}\right\|_{2} \leq a^{-1} \gamma_{\tilde{s}, \tilde{q}, 0} C_{\tilde{l}_{a}}\left\|\tilde{l}_{a} \tilde{y}\right\|_{2} .
$$

By (3.16), $\tilde{\tilde{l}}=\tilde{\tilde{l}}_{a}+a^{3} \tilde{s} E$. Choosing the number $a$ such as $a=2 C_{\tilde{l}_{a}}\left(1+\gamma_{\tilde{s}, \tilde{q}, 0}\right)$, we obtain

$$
\left\|a^{3} \tilde{s} \tilde{y}\right\|_{2} \leq \alpha\left\|\tilde{\tilde{l}_{a}} \tilde{y}\right\|_{2}, 0<\alpha \leq \frac{1}{2}
$$

Then, by the well-known perturbation theorem (for example, see Theorem $1.16[38 ; 196])$, there exists the inverse operator $\left(\tilde{\tilde{l}}_{a}+a^{3} \tilde{s} E\right)^{-1}$ and the equality $R\left(\tilde{\tilde{l}}_{a}+a^{3} \tilde{s} E\right)=L_{2}$ is true. By estimates (3.17) and (3.18),

$$
\left\|\tilde{y}^{\prime \prime \prime}\right\|_{2}+\left\|a^{2} \tilde{q} \tilde{y}^{\prime}\right\|_{2}+\left\|a^{3} \tilde{s} \tilde{y}\right\|_{2} \leq\left(C_{\tilde{l}}+\frac{1}{2}\right)\|\tilde{\tilde{l}} a \tilde{y}\|_{2} .
$$

On the other hand, by (3.18),

i.e.

$$
\left\|\tilde{\tilde{l}}_{a} \tilde{y}\right\|_{2} \leq\left\|\left(\tilde{\tilde{l}}_{a}+a^{3} \tilde{s} E\right) \tilde{y}\right\|_{2}+\frac{1}{2}\left\|\tilde{\tilde{l}}_{a} \tilde{y}\right\|_{2}
$$

$$
\left\|\tilde{\tilde{l}}_{a} \tilde{y}\right\|_{2} \leq 2\left\|\left(\tilde{\tilde{l}}_{a}+a^{3} \tilde{s} E\right) \tilde{y}\right\|_{2} .
$$

The estimates (3.19) and (3.20) imply

$$
\left\|\tilde{y}^{\prime \prime \prime}\right\|_{2}+\left\|a^{2} \tilde{q} \tilde{y}^{\prime}\right\|_{2}+\left\|a^{3} \tilde{s} \tilde{y}\right\|_{2} \leq C\|\tilde{u}\|_{2}, C=2\left(C_{\tilde{l}_{a}}+\frac{1}{2}\right) .
$$

By replacing $t=a^{-1} x$, we obtain the estimate (3.15). 
Proof of Theorem 1.2. If the conditions (1.9) and (1.10) hold, then by Lemma 3.3, the operator

$$
\tilde{l} y=-y^{\prime \prime \prime}+q(x) y^{\prime}+s(x) y
$$

is continuously invertible, and for any $y \in D(\tilde{l})$ the following estimate holds:

$$
\left\|y^{\prime \prime \prime}\right\|_{2}+\left\|q y^{\prime}\right\|_{2}+\|s y\|_{2} \leq C_{\tilde{l}}\|\tilde{l} y\|_{2} .
$$

Taking into account the condition (1.11), for any $y \in C_{0}^{(3)}(R)$ we obtain

$$
\left\|r y^{\prime \prime}\right\|_{2}^{2} \leq \frac{1}{4}\left\|y^{\prime \prime \prime}\right\|_{2}^{2}+\left\|r^{2} y^{\prime}\right\|_{2}^{2}+\left\|2 r^{\prime} y^{\prime}\right\|_{2}^{2}+\frac{1}{4}\left\|r y^{\prime \prime}\right\|_{2}^{2} .
$$

Then, by (3.15),

so,

$$
\left\|r y^{\prime \prime}\right\|_{2}^{2} \leq \frac{1}{3}\left(\left\|y^{\prime \prime \prime}\right\|_{2}^{2}+\left\|2\left(r^{2}+2 r^{\prime}\right) y^{\prime}\right\|_{2}^{2}+\|s y\|_{2}^{2}\right) \leq \frac{1}{3}\|\tilde{\tilde{l}} y\|_{2}^{2}
$$

$$
\left\|r y^{\prime \prime}\right\|_{2} \leq \frac{1}{\sqrt{3}}\|\tilde{\tilde{l}} y\|_{2} .
$$

It is clear that this inequality holds for any $y \in D(\tilde{\tilde{l}})$. Then by Theorem $1.16[38 ; 196]$ the operator $L y=\tilde{\tilde{l}} y+r y^{\prime \prime}$ is closed and invertible, and its inverse $L^{-1}$ is defined in all of $L_{2}$. By (3.22), for any $y \in C_{0}^{(3)}(R)$

$$
\|\tilde{l} y\|_{2} \leq \frac{\sqrt{3}}{\sqrt{3}-1}\|L y\|_{2} .
$$

Then, by (3.21) and (3.22), for any $y \in C_{0}^{(3)}(R)$ holds the estimate $(1.2)$, where $C_{L}=\frac{1+\sqrt{3} C_{L}}{\sqrt{3}-1}$. Taking into account that the operator $L$ is closed, we obtain that the last estimate holds for a solution of the equation (1.1).

Example 3.1. We consider the following equation

$$
-y^{\prime \prime \prime}+x^{3} \cos ^{2} x^{2} y^{\prime \prime}+\left[18\left(1+x^{6}\right)\right] y^{\prime}+3 x^{4} y=f_{2}(x), x \in R, f_{2}(x) \in L_{2} .
$$

The coefficients $r=x^{3} \cos ^{2} x^{2}, q=18\left(1+x^{6}\right)$ and $s=3 x^{4}$ of this equation satisfy all of the conditions of Theorem 1.2. In fact,

$$
\alpha_{1, \sqrt{q}, 0}(x)=\beta_{1, \sqrt{q}, 0}(-x) \leq \sqrt{x}\left(\int_{x}^{+\infty} \frac{d t}{18\left(t^{6}+1\right)}\right)^{\frac{1}{2}}<\infty, x>0 .
$$

For any $x, \eta \in R$ such that $|x-\eta| \leq 1$ we obtain

$$
\frac{18\left(1+x^{6}\right)}{18\left(1+\eta^{6}\right)} \leq \frac{1+(1+\eta)^{6}}{1+\eta^{6}}<\infty
$$

Further,

$$
\begin{gathered}
\alpha_{s, q, 0}(x)=\beta_{s, q, 0}(-x) \leq x^{\frac{9}{2}}\left(\int_{x}^{+\infty} \frac{d t}{18^{2}\left(t^{6}+1\right)^{2}}\right)^{\frac{1}{2}}<\infty, x>0 . \\
2\left(r^{2}+2 r^{\prime}\right)=2\left(x^{6}+8|x|^{4}+1\right) \leq 18\left(x^{6}+1\right)=q .
\end{gathered}
$$

So, by Theorem 1.2, for any $f_{2} \in L_{2}$ there exists the unique solution $y$ of the equation (1.12), and for $y$ the following estimate holds:

$$
\left\|-y^{\prime \prime \prime}\right\|_{2}+\left\|x^{3} \cos ^{2} x^{2} y^{\prime \prime}\right\|_{2}+\left\|\left[18\left(1+x^{6}\right)\right] y^{\prime}\right\|_{2}+\left\|3 x^{4} y\right\|_{2} \leq C\left\|f_{2}\right\|_{2} .
$$

This work is partially supported by project AP05131649/GF5 of the Science Committee of the Ministry of Education and Science of the Republic of Kazakhstan and by the L.N. Gumilyov Eurasian National University Research Fund. 


\section{References}

1 Galaktionov V.A. Ordered invariant sets for KdV-type nonlinear evolution equations/ V.A. Galaktionov // Computational Mathematics and Mathematical Physics. - 1999. - Vol. 39, № 9. - P. 1564-1570.

2 Kozhanov A.I. Composite type equations and inverse problems / A.I. Kozhanov // VSP, Utrecht, the Netherlands. - 1999.

3 Maxworthy T.A Solitary wave theory of the great red spot and other observed features in the Jovian atmosphere / T. Maxworthy, L.G. Redekopp // Icarus. - 1976. - Vol. 29, Issue 2. - P. 261-271. DOI: 10.1016/0019-1035(76)90056-7.

4 Perel'man T.L. A modified Korteweg-de Vries equation in electrohydrodynamics / T.L. Perel'man, A.X. Fridman, M.M. El'yashevich // Journal of Experimental and Theoretical Physics. - 1974. - Vol. 66. - P. 1316-1323.

5 Liu C.H. Propagation of pulse trains through a random / C.H. Liu, A.W. Weznik, K.C. Yeh // Ieee Transactions on Antennas and Propagation. - 1974. - Vol. 22, Issue 4. - P. 184-187. DOI: 10.1109/TAP. 1974.1140830.

6 Taimanov I.A. Finite-gap solutions of the modified novikov-veselov equations: Their spectral properties and applications / I.A. Taimanov // Siberian Mathematical Journal. - 1999. - Vol. 40, № 6. - P. 11461156. DOI: $10.1007 /$ BF02677539.

7 Kunstmann P.C. Maximal $L_{p}$-regularity for Parabolic Equations, Fourier Multiplier Theorems and $H^{\infty}$-functional Calculus / P.C. Kunstmann, L. Weis // Functional Analytic Methods for Evolution Equations. Lecture Notes in Mathematics, 1855. - Springer-Verlag, Berlin, Heidelberg, 2004. - P. 65-311. DOI: $10.1007 / 978-3-540-44653-8-2$.

8 Arendt W. Maximal $L_{p}$-regularity for parabolic and elliptic equations on the line / W. Arendt, M. Duelli // Journal of Evolution Equations. - 2006. - Vol. 6, Issue 4. - P. 773-790. DOI: 10.1007/s00028-0060292-5.

9 Metafune G. $L_{p}$-theory for elliptic operators on $R^{d}$ with singular coefficients / G. Metafune, D. Pallara, J. Prüss, R. Schnaubelt // Z. Anal. Anwendungen. Journal for Analysis and its Applications. - 2005. Vol. 24, № 3. - P. 497-521.

10 Metafune G. $L_{p}$-regularity for elliptic operators with unbounded coefficients / G. Metafune, J. Prüss, R. Schnaubelt, A. Rhandi // Advances in Differential Equations. - 2005. - Vol. 10, No. 10. - P. 1131-1164

11 Ospanov K. Separation and the existence for second order nonlinear differential equation / K. Ospanov, R. Akhmetkaliyeva // Electronic Journal of Qualitative Theory of Differential Equations. - 2012, No. 66. - P. 1-12.

12 Аманова Т.Т. О разделимости одного дифференциального оператора / Аманова Т.Т. // Известия АН КазССР. Сер. физ.-мат. - 1981. - № 3. - С. 48-51.

13 Аманова Т.Т. Гладкость решения одного нелинейного дифференциального уравнения / Т.Т. Аманова, М.В. Муратбеков // Известия АН КазССР. Сер. физ.-мат. - 1983, № 5. - С. 4-7.

14 Биргебаев А. О разделимости нелинейного дифференциального оператора третьего порядка / А. Биргебаев, М. Отелбаев // Известия АН КазССР. Сер. физ.-мат. - 1984, № 3. - С. 11- 13.

15 Тогочуев А.Ж. О суммируемости решений дифференциальных уравнений нечетного порядка с весом / А.Ж. Тогочуев // Изв. АН КазССР. Сер. физ.-мат. - 1985, № 5. - С. 55-58.

16 Сапенов М. О суммируемости с весом решений двучленных дифференциальных уравнений / М. Сапенов, L.A. Shuster // Изв. АН КазССР. Сер. физ.-мат. - 1987, № 1. - С. 38-42.

17 Айткожа Ж.Ж. О разрешимости одного класса нелинейных сингулярных уравнений третьего порядка / Ж.Ж. Айткожа, М.В. Муратбеков, К.Н. Оспанов // Вестн. ЕНУ им. Л.Н. Гумилева. - 2005, № 6 (46). - C. 10-15.

18 Muratbekov M.B. Coercive solvability of odd-order differential equations and its applications / M.B. Muratbekov, M.M. Muratbekov, K.N. Ospanov // Doklady Mathematics. - 2010. - Vol. 82, No. 3. P. 909-911. DOI: 10.1134/S1064562410060189.

19 Akhmetkaliyeva R.D. Some new results concerning a class of third order differential equations / R.D. Akhmetkaliyeva, L.E. Persson, K. Ospanov, P. Woll // Applicable Analysis: An International Journal. - 2015. - Vol. 94, Issue 2. - P. 419-434. DOI: 10.1080/00036811.2014.898375. 
20 Albanese A. $L_{p}$-uniqueness for elliptic operators with unbounded coefficients in $R^{N} /$ A. Albanese, L. Lorenzi, E.M. Mangino // Journal of Functional Analysis. - 2009. - Vol. 256, No. 4. - P. 1238 1257. DOI: $10.1016 /$ j.jfa.2008.07.022.

21 Albanese A.A. Cores for Feller semigroups with an invariant measure / A.A. Albanese, E.M. Mangino // Journal of Differential Equations. - 2008. - Vol. 244, No. 11. - P. 2980-2982. DOI: 10.1016/j.jde.2005.09.014.

22 Da Prato G. On a class of self-adjoint elliptic operators in $L_{2}$ spaces with respect to invariant measure / G. Da Prato, A. Lunardi // Journal of Differential Equations. - 2007. - Vol. 234, No. 1. - P. 54-79. DOI: $10.1016 /$ j.jde.2006.11.017.

23 Da Prato G. Maximal $L_{p}$ regularity for elliptic equations with unbounded coefficients / G. Da Prato, V. Vespri // Journal of Differential Equations. - 2002. - Vol. 49, No. 6. - P. 747-755. DOI: 10.1016/S0362$546 \mathrm{X}(01) 00133-\mathrm{X}$.

24 Hieber M. Global properties of generalized Ornstein-Uhlenbeck operators on $L_{p}\left(R^{N}, R^{N}\right)$ with more than linearly growing coefficients / M. Hieber, L. Lorenzi, J. Pruss, A. Rhandi, R. Schnaubelt // Journal of Mathematical Analysis and Applications. - 2009. - Vol. 350, No. 1. - P. 100-121. DOI: 10.1016/j.jmaa. 2008.09.011

25 Lunardi A. On the Ornstein-Uhlenbeck operator in $L_{2}$ spaces with respect to invariant measures / A. Lunardi // Transactions of the American Mathematical Society. - 1997. - Vol. 349, No. 1. P. $155-169$.

26 Ospanov K.N. Qualitative and approximate characteristics of solutions of Beltrami-type systems / K.N. Ospanov // Complex variables and elliptic equations. - 2015. - Vol. 60, Issue 7. - P. 1005-1014. DOI: $10.1080 / 17476933.2015 .1025066$.

27 Ospanov K.N. On the nonlinear generalized Cauchy-Riemann system on the whole plane / K.N. Ospanov // Siberian Mathematical Journal. - 1997. - Vol. 38, Issue 2. - P. 314-319. DOI: $10.1007 /$ BF02674630.

28 Ospanov K. L1-maximal regularity for quasilinear second order differential equation with damped term / K. Ospanov // Electronic Journal of Qualitative Theory of Differential Equations. - 2015. - Vol. 39. - P. 1-9.

$29 \mathrm{Wu}$ L.M. A new topological approach to the $L^{\infty}$-uniqueness of operators and the $L^{1}$-uniqueness of Fokker-Planck equations/ L.M. Wu, Y. Zhang // Journal of Functional Analysis. - 2006. - Vol. 241, No. 2. - P. 557-610. DOI: 10.1016/j.jfa.2006.04.020.

30 Metafune G. $L_{p}$-spectrum of Ornstein-Uhlenbeck operators / G. Metafune // Annali della Scuola normale superiore di Pisa, Classe di scienze. - 2001. - Vol. 30, No. 1. - P. 97-124.

31 Metafune G. Long time behavior of heat kernels of operators with unbounded drift terms / G. Metafune, E.M. Ouhabaz, D. Pallara // Journal of Mathematical Analysis and Applications. - 2011. - Vol. 377, No. 1. - P. 170-179. DOI: 10.1016/j.jmaa.2010.10.023.

32 Metafune G. Spectrum of Ornstein-Uhlenbeck operators in $L_{p}$ spaces with respect to invariant measures / G. Metafune, D. Pallara, E. Priola // Journal of Functional Analysis. - 2002. - Vol. 196, No. 1. P. 40-60. DOI: $10.1006 /$ jfan.2002.3978.

33 Metafune G. The domain of the Ornstein-Uhlenbeck operator on an $L_{p}$-space with invariant measure / G. Metafune, J. Pruss, A. Rhandi, R. Schnaubelt // Annali della Scuola Normale Superiore di Pisa Classe di Scienze. - 2002. - Vol. 1, No. 2. - P. 471-485.

34 Ospanov K.N. On Coercive Solvability of a Third-Order Differential Equation with Oscillating Intermediate Coefficient / K.N. Ospanov, Zh.B. Yeskabylova // AIP Conference Proceedings. - 2018. - Vol.1997. P. 020055-1-020055-4. DOI: 10.1063/1.5049049.

35 Ospanov K.N. On smoothness property of third-order differential operator / K.N. Ospanov, Zh.B. Yeskabylova // AIP Conference Proceedings. - 2017. - Vol. 1880. - P. 040009-1-040009-6. DOI: $10.1063 / 1.5000625$.

36 Оспанов К.Н. Үшінші ретті бір нұқсанды дифференциалдық оператордың анықталу облысын сипаттау / К.Н. Оспанов, Ж.Б. Ескабылова // Л.Н. Гумилев атындағы ЕҰУ хабаршысы, І-б. - 2017. - Т. 121, № 6. - 30-36-б. 
37 Apyshev O.D. On the spectrum of a class of differential operators and some imbedding theorems / O.D. Apyshev, M. Otelbaev // Mathematics of the USSR-Izvestiya. - 1980. - Vol. 15, No. 1. P. 739-764. DOI: 10.1070/IM1980v015n01ABEH001190.

38 Kato T. Perturbation theory for linear operators / T. Kato. - Springer, 1995.

39 Мынбаев К.Т. Весовые функциональные пространства и спектр дифференциальных операторов / К.Т. Мынбаев, М. Отелбаев. - М.: Наука, 1990.

Қ.Н. Оспанов, Ж.Б. Ескабылова

\title{
Аралық коэффициенттері шенелмеген үшінші ретті дифференциалдық теңдеудің коэрцитивті шешілу шарттары
}

\begin{abstract}
Мақалада келесі теңдеу қарастырылған: $-y^{\prime \prime \prime}+r(x) y^{\prime \prime}+q(x) y^{\prime}+s(x) y=f(x)$, мұндағы $r$ және $q$ - аралық коэффициенттер, $s$-қа бағынбайды. Осы теңдеудің $f \in L_{2}(-\infty,+\infty)$ үшін коэрцитивті шешілу шарттары келтірілген. Және $y$ шешім үшіні келесі максималды регулярлық баға алынған: $\left\|y^{\prime \prime \prime}\right\|_{2}+\left\|r y^{\prime \prime}\right\|_{2}+\left\|q y^{\prime}\right\|_{2}+\|s y\|_{2} \leq C\|f\|_{2},-$ мұндағы $\|\cdot\|_{2}-L_{2}(-\infty,+\infty)$-дегі норма. Бұл бағалау $(-\infty,+\infty)$ аралығындағы үшінші ретті квазисызықты дифференциалдық теңдеуді зерттеуде маңызды рөл атқарады. Кейбір екімүшелі нұқсанды дифференциалдық теңдеулер қарастырылып, олардың коэрцитивті шешілуі дәлелденді. Бұл жерде М. Өтелбаев жасаған Гильберт кеңістігіндегі дифференциалдық оператордың бөліктену теориясы әдісі қолданылды. Осы көмекші тұжырымдарды және кейбір белгілі Харди типті салмақты интегралдық теңсіздіктер арқылы қажетті нәтижеге қолжеткізілді. Осыған дейін алынған нәтижелермен салыстырғанда авторлар $s$ потенциалы қатаң оң деп ұйғарып, нәтижелері $s=0$ жағдайы үшін де орынды деп қорытынды жасады.
\end{abstract}

Кілт сөздер: дифференциалдық теңдеу, шенелмеген коэффициенттер, максималды регулярлы, бөліктену.

К.Н. Оспанов, Ж.Б. Ескабылова

\section{Условия коэрцитивной разрешимости дифференциального уравнения третьего порядка с неограниченными промежуточными коэффициентами}

В статье рассмотрено уравнение: $-y^{\prime \prime \prime}+r(x) y^{\prime \prime}+q(x) y^{\prime}+s(x) y=f(x)$, в котором промежуточные коэффициенты $r$ и $q$ не зависят от $s$. Приведены условия коэрцитивной разрешимости этого уравнения для $f \in L_{2}(-\infty,+\infty)$. Для решения $y$ получена следующая оценка максимальной регулярности: $\left\|y^{\prime \prime \prime}\right\|_{2}+\left\|r y^{\prime \prime}\right\|_{2}+\left\|q y^{\prime}\right\|_{2}+\|s y\|_{2} \leq C\|f\|_{2}$, где $\|\cdot\|_{2}-$ норма в $L_{2}(-\infty,+\infty)$. Эта оценка важна для изучения квазилинейного дифференциального уравнения третьего порядка в $(-\infty,+\infty)$. Исследованы некоторые двучленные вырожденные дифференциальные уравнения и доказаны, что они являются коэрцитивно разрешимыми. Здесь применен метод теории разделимости дифференциальных операторов в гильбертовом пространстве, разработанный М. Отелбаевым. С помощью этих вспомогательных утверждений и некоторых известных весовых интегральных неравенств типа Харди получен желаемый результат. В отличие от предварительных результатов, авторы предполагают, что потенциал $s$ является строго положительным, результаты также справедливы в случае, когда $s=0$.

Ключевые слова: дифференциальное уравнение, неограниченные коэффициенты, максимальная регулярность, разделимость. 


\section{References}

1 Galaktionov, V.A. (1999). Ordered invariant sets for KdV-type nonlinear evolution equations. Computational Mathematics and Mathematical Physics, Vol. 39, No. 9, 1564-1570.

2 Kozhanov, A.I. (1999). Composite type equations and inverse problems. VSP, Utrecht, the Netherlands.

3 Maxworthy, T., \& Redekopp, L.G. (1976). A solitary wave theory of the great red spot and other observed features in the Jovian atmosphere. Icarus, Vol. 29, Issue 2, 261-271. DOI: 10.1016/00191035(76)90056-7.

4 Perel'man, T.L., Fridman, A.X., \& El'yashevich, M.M. (1974). A modified Korteweg-de Vries equation in electrohydrodynamics. Journal of Experimental and Theoretical Physics, Vol. 66, 1316-1323.

5 Liu, C.H., Weznik, A.W., \& Yeh, K.C. (1974). Propagation of pulse trains through a random. Ieee Transactions on Antennas and Propagation, Vol. 22, Issue 4, 184-187. DOI: 10.1109/TAP.1974.1140830.

6 Taimanov, I.A. (1999). Finite-gap solutions of the modified Novikov-Veselov equations: Their spectral properties and applications. Siberian Mathematical Journal, Vol. 40, 6, 1146-1156. DOI: $10.1007 /$ BF02677539.

7 Kunstmann, P.C., \& Weis, L. (2004). Maximal $L_{p}$-regularity for Parabolic Equations, Fourier Multiplier Theorems and $H^{\infty}$-functional Calculus. Functional Analytic Methods for Evolution Equations. Lecture Notes in Mathematics, 1855. Springer-Verlag, Berlin, Heidelberg, 5-311. DOI: 10.1007 /978-3-540-44653$8-2$.

8 Arendt, W., \& Duelli, M. (2006). Maximal $L_{p}$-regularity for parabolic and elliptic equations on the line. Journal of Evolution Equations, Vol. 6, Issue 4, 773-790. DOI: 10.1007/s00028-006-0292-5.

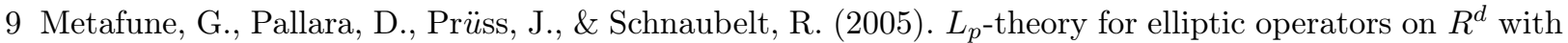
singular coefficients. Z. Anal. Anwendungen. Journal for Analysis and its Applications, Vol. 24, No. 3, $497-521$.

10 Metafune, G., Prüss, J., Schnaubelt, R., \& Rhandi, A. (2005). $L_{p}$-regularity for elliptic operators with unbounded coefficients. Advances in Differential Equations, Vol. 10, No. 10, 1131-1164.

11 Ospanov, K., \& Akhmetkaliyeva, R. (2012). Separation and the existence for second order nonlinear differential equation. Electronic Journal of Qualitative Theory of Differential Equations, No. 66, 1-12.

12 Amanova, T.T. (1981). O razdelimosti odnoho differentsialnoho operatora [On the separability of a single differential operator]. Izvestiia AN KazSSR. Seriia fiziko-matematicheskaiia - News of AS of Kazakh SSR. Physics and Mathematics Series, 3, 48-51 [in Russian].

13 Amanova, T.T., \& Muratbekov, M.B. (1983). Hladkost resheniia odnoho nelineinoho differentsialnoho uravneniia [The smoothness of solution of a single nonlinear differential equation]. Izvestiia AN KazSSR. Seriia fiziko-matematicheskaiia - News of AS of Kazakh SSR. Physics and Mathematics Series, 5, 4-7 [in Russian].

14 Birgebaev, A., \& Otelbaev, M. (1984). O razdelimosti nelineinoho differentsialnoho operatora treteho poriadka [On the separability of a third-order nonlinear differential operator]. Izvestiia AN KazSSR. Seriia fiziko-matematicheskaiia - News of AS of Kazakh SSR. Physics and Mathematics Series, 3, 11-13 [in Russian].

15 Togochuev, A.Zh. (1985). O summiruemosti reshenii differentsialnykh uravnenii nechetnoho poriadka s vesom [On the summability of solutions of differential equations of odd order with weight]. Izvestiia AN KazSSR. Seriia fiziko-matematicheskaiia - News of AS of Kazakh SSR. Physics and Mathematics Series, 5, 55-58 [in Russian].

16 Sapenov, M., \& Shuster, L.A. (1987). O summiruemosti s vesom reshenii dvuchlennykh differentsialnykh uravnenii [On summability with the weight of solutions of two-term differential equations]. Izvestiia AN KazSSR. Seriia fiziko-matematicheskaiia - News of AS of Kazakh SSR. Physics and Mathematics Series, 1, 38-42 [in Russian].

17 Aitkozha, Zh.Zh., Muratbekov, M.B., \& Ospanov, K.N. (2005). O razreshimosti odnoho klassa nelineinykh sinhuliarnykh uravnenii treteho poriadka [On the solvability of a single class of third order nonlinear singular equations]. Vestnik ENU imeni L.N. Gumilyova - Bulletin of L.N. Gumilyov ENU, 6(46), 10-15 [in Russian]. 
18 Muratbekov, M.B., Muratbekov, M.M., \& Ospanov, K.N. (2010). Coercive Solvability of odd-order differential equations and its applications. Doklady mathematics, Vol. 82, No. 3, 909-911. DOI: 10.1134/ S1064562410060189.

19 Akhmetkaliyeva, R.D., Persson, L.E., Ospanov, K., \& Woll P. (2015). Some new results concerning a class of third order differential equations. Applicable Analysis: An International Journal, Vol. 94, Issue 2, 419-434. DOI: 10.1080/00036811.2014.898375.

20 Albanese, A., Lorenzi, L., \& Mangino, E.M. (2009). $L_{p}$-uniqueness for elliptic operators with unbounded coefficients in $R^{N}$. Journal of Functional Analysis, Vol. 256, No. 4, 1238-1257. DOI: 10.1016/j.jfa.2008.07.022.

21 Albanese, A.A., \& Mangino, E.M. (2008). Cores for Feller semigroups with an invariant measure. Journal of Differential Equations, Vol. 244, No. 11, 2980-2982. DOI: 10.1016/j.jde.2005.09.014.

22 Da Prato, G., \& Lunardi, A. (2007). On a class of self-adjoint elliptic operators in $L_{2}$ spaces with respect to invariant measure. Journal of Differential Equations, Vol. 234, 1, 54-79. DOI: 10.1016/j.jde.2006.11.017.

23 Da Prato, G., \& Vespri, V. (2002). Maximal $L_{p}$-regularity for elliptic equations with unbounded coefficients. Journal of Differential Equations, Vol. 49, No. 6, 747-755. DOI: 10.1016/S0362-546X(01) 00133-X.

24 Hieber, M., Lorenzi, L., Pruss, J., Rhandi, A., \& Schnaubelt, R. (2009). Global properties of generalized Ornstein-Uhlenbeck operators on $L_{p}\left(R^{N}, R^{N}\right)$ with more than linearly growing coefficients. Journal of Mathematical Analysis and Applications, Vol. 350, No. 1, 100-121. DOI: 10.1016/j.jmaa.2008.09.011.

25 Lunardi, A. (1997). On the Ornstein-Uhlenbeck operator in $L_{2}$ spaces with respect to invariant measures. Transactions of the American Mathematical Society, Vol. 349, No. 1, 155-169.

26 Ospanov, K.N. (2015). Qualitative and approximate characteristics of solutions of Beltrami-type systems. Complex variables and elliptic equations, Vol. 60, Issue 7, 1005-1014. DOI: 10.1080/ 17476933.2015.1025066.

27 Ospanov, K.N. (1997). On the nonlinear generalized Cauchy-Riemann system on the whole plane. Siberian Mathematical Journal, Vol. 38, Issue 2, 314-319. DOI: 10.1007/BF02674630.

28 Ospanov, K. (2015). L1-maximal regularity for quasilinear second order differential equation with damped term. Electronic Journal of Qualitative Theory of Differential Equations, Vol. 39, 1-9.

$29 \mathrm{Wu}$, L.M., \& Zhang, Y. (2006). A new topological approach to the $L^{\infty}$-uniqueness of operators and the $L^{1}$-uniqueness of Fokker-Planck equations. Journal of Functional Analysis, Vol. 241, No. 2, 557-610. DOI: $10.1016 /$ j.jfa.2006.04.020.

30 Metafune, G. (2001). $L_{p}$-spectrum of Ornstein-Uhlenbeck operators. Annali della Scuola normale superiore di Pisa, Classe di scienze, Vol. 30, No. 1, 97-124.

31 Metafune, G., Ouhabaz, E.M., \& Pallara, D. (2011). Long time behavior of heat kernels of operators with unbounded drift terms. Journal of Mathematical Analysis and Applications, Vol. 37r, No. 1, 170-179. DOI: $10.1016 /$ j.jmaa.2010.10.023.

32 Metafune, G., Metafune, G., Pallara, D., \& Priola, E. (2002). Spectrum of Ornstein-Uhlenbeck operators in $L_{p}$ spaces with respect to invariant measures. Journal of Functional Analysis, Vol. 196, No. 1, 40-60. DOI: $10.1006 /$ jfan.2002.3978.

33 Metafune, G., Pruss, J., Rhandi, A., \& Schnaubelt, R. (2002). The domain of the Ornstein-Uhlenbeck operator on an $L_{p}$-space with invariant measure. Annali della Scuola Normale Superiore di Pisa - Classe di Scienze, Vol. 1, No. 2, 471-485.

34 Ospanov, K.N., \& Yeskabylova, Zh.B. (2018). On Coercive Solvability of a Third-Order Differential Equation with Oscillating Intermediate Coefficient. AIP Conference Proceedings, Vol. 1997, 020055-1-020055-4. DOI: $10.1063 / 1.5049049$.

35 Ospanov, K.N., \& Yeskabylova, Zh.B. (2017). On smoothness property of third-order differential operator. AIP Conference Proceedings, Vol. 1880, 040009-1-040009-6. DOI: 10.1063/1.5000625.

36 Ospanov, K.N., \& Yeskabylova, Zh.B. (2017). Ushinshi retti bir nuksandy differencialdyk operatordyn anyktalu oblysyn sipattau [Description of the domain of definition of a third order degenerate differential operator]. Vestnik ENU imeni L.N. Gumileva - Bulletin of L.N. Gumilyov ENU, Vol. 121, No. 6, 30-36 [in Kazakh]. 
37 Apyshev, O.D., \& Otelbaev, M. (1980). On the spectrum of a class of differential operators and some imbedding theorems. Mathematics of the USSR-Izvestiia, Vol. 15, 1, 739-764. DOI: 10.1070/IM1980v015n 01ABEH001190.

38 Kato, T. (1995). Perturbation theory for linear operators. Springer.

39 Mynbaev, K.T., \& Otelbaev, M. (1990). Vesovye funktsionalnye prostranstva i spektr differentsialnykh operatorov [Weighted functional spaces and the spectrum of the differential operators]. Moscow: Nauka [in Russian]. 